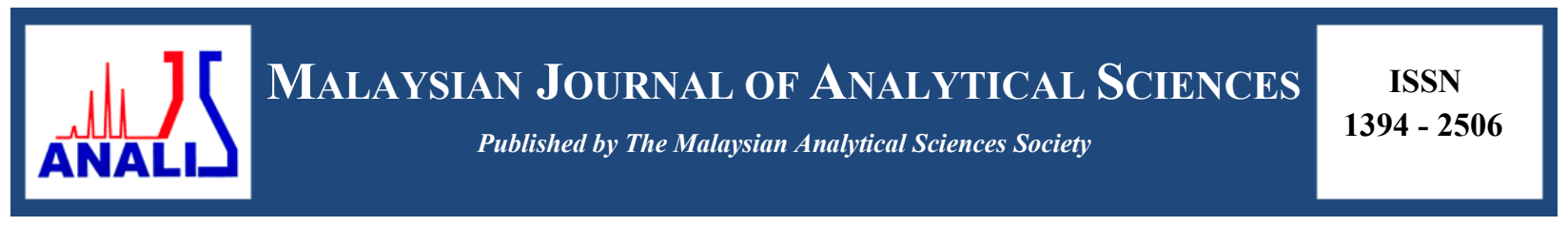

\title{
SYNTHESIS OF ALUMINA-CaO-KI CATALYST FOR THE PRODUCTION OF BIODIESEL FROM RUBBER SEED OIL
}

\author{
(Sintesis Mangkin Alumina-CaO-KI untuk Penghasilan Biodiesel daripada Minyak Biji Getah) \\ Zainal Kifli Abdul Razak ${ }^{1 *}$, Shahida Hanum Kamarullah ${ }^{1}$, Siti Norhafiza Mohd Khazaai ${ }^{1,2}$, \\ Gaanty Pragas Maniam ${ }^{2}$ \\ ${ }^{I}$ Faculty of Applied Sciences, \\ Universiti Teknologi MARA Pahang, 26400 Bandar Tun Abdul Razak, Jengka, Pahang, Malaysia \\ ${ }^{2}$ Faculty of Industrial Sciences \& Technology, \\ Universiti Malaysia Pahang, Lebuhraya Tun Razak, 26300 Gambang, Pahang, Malaysia \\ *Corresponding author: zainalk@uitm.edu.my
}

Received: 4 December 2016; Accepted: 1 December 2017

\begin{abstract}
In this research, biodiesel was produced by transesterification of rubber seed oil with methanol catalyzed by three types of alumina-supported catalyst. The catalysts were $\mathrm{Al}_{2} \mathrm{O}_{3}-\mathrm{CaO}, \mathrm{Al}_{2} \mathrm{O}_{3}-\mathrm{KI}$, and $\mathrm{Al}_{2} \mathrm{O}_{3}-\mathrm{CaO}-\mathrm{KI}$. The catalysts were prepared by heating a mixture of alumina and the corresponding salt in a furnace at $700{ }^{\circ} \mathrm{C}$. Transesterification reactions were carried out at $65{ }^{\circ} \mathrm{C}$ using a mixture of rubber seed oil: methanol of mass ratio 1:9 with different catalyst loadings between 0 and $3.5 \%$. The optimum catalyst loading was at $2.0 \%$ for all types of catalyst and $\mathrm{Al}_{2} \mathrm{O}_{3}-\mathrm{CaO}-\mathrm{KI}$ gave the highest yield $(91.6 \%)$ followed by $\mathrm{Al}_{2} \mathrm{O}_{3}-\mathrm{KI}$ (90.7\%) and $\mathrm{Al}_{2} \mathrm{O}_{3}-\mathrm{CaO}$ (63.5\%). The catalyst $\mathrm{Al}_{2} \mathrm{O}_{3}-\mathrm{CaO}-\mathrm{KI}$ also gave high biodiesel yields over a wider range of catalyst loadings compared to the other two catalysts. Reactions were also carried out at different temperatures $\left(25,40\right.$ and $\left.65^{\circ} \mathrm{C}\right)$. It was observed that the yield increased drastically with increasing reaction temperature. At all temperatures the $\mathrm{Al}_{2} \mathrm{O}_{3}-\mathrm{CaO}-\mathrm{KI}$ catalyst gave the highest yield. Therefore, the study showed that among these three catalysts the most productive was $\mathrm{Al}_{2} \mathrm{O}_{3}-\mathrm{CaO}-\mathrm{KI}$, $(100: 30: 35)$.
\end{abstract}

Keywords: alumina-supported catalyst, biodiesel, rubber seed oil, transesterification

\begin{abstract}
Abstrak
Dalam kajian ini, biodiesel dihasilkan melalui tindak balas transesterifikasi minyak biji getah dengan metanol menggunakan tiga jenis mangkin tersokong alumina. Mangkin-mangkin tersebut adalah $\mathrm{Al}_{2} \mathrm{O}_{3}-\mathrm{CaO}, \mathrm{Al}_{2} \mathrm{O}_{3}-\mathrm{KI}$ dan $\mathrm{Al}_{2} \mathrm{O}_{3}-\mathrm{CaO}-\mathrm{KI}$. Mangkinmangkin itu disediakan dengan pemanasan campuran alumina dan garam yang berkaitan di dalam relau pada suhu $700{ }^{\circ} \mathrm{C}$. Tindak balas transesterifikasi dijalankan pada suhu $65^{\circ} \mathrm{C}$ dengan menggunakan campuran minyak biji getah: metanol dengan nisbah jisim 1:9 dengan beban mangkin yang berbeza di antara 0 hingga 3.5\%. Beban mangkin yang optimum adalah $2.0 \%$ untuk semua jenis mangkin dan mangkin $\mathrm{Al}_{2} \mathrm{O}_{3}-\mathrm{CaO}-\mathrm{KI}$ memberikan peratus hasil yang paling tinggi $(91.6 \%)$ diikuti oleh $\mathrm{Al} 2 \mathrm{O}_{3}-\mathrm{KI}$ (90.7\%) dan $\mathrm{Al}_{2} \mathrm{O}_{3}-\mathrm{CaO}$ (63.5\%). Mangkin $\mathrm{Al}_{2} \mathrm{O}_{3}-\mathrm{CaO}-\mathrm{KI}$ juga memberikan peratus hasil biodiesel yang tinggi pada julat beban mangkin yang lebih besar berbanding dengan dua mangkin yang lain. Tindak balas juga dijalankan pada suhu-suhu yang berbeza $\left(25,40\right.$ dan $\left.65^{\circ} \mathrm{C}\right)$. Didapati bahawa peratus hasil meningkat secara mendadak dengan peningkatan suhu tindak balas. Pada sebarang suhu mangkin $\mathrm{Al}_{2} \mathrm{O}_{3}-\mathrm{CaO}-\mathrm{KI}$ memberikan peratus hasil yang paling tinggi. Oleh itu, kajian ini menunjukkan bahawa di antara ketiga-tiga jenis mangkin ini $\mathrm{Al}_{2} \mathrm{O}_{3}-\mathrm{CaO}-\mathrm{KI},(100: 30: 35)$ adalah yang paling produktif.
\end{abstract}

Kata kunci: mangkin tersokong alumina, biodiesel, minyak biji getah, transesterifikasi 


\section{Introduction}

The excessive use of fossil fuels has stirred environmental concern due to their non-renewable nature. Therefore, as an alternative biodiesel is becoming a popular choice of renewable fuel. Biodiesels are fatty acid methyl esters that can be produced from fats or oils from plants or animals. There are two chemical reactions which can be used to produce biodiesel, namely esterification, and transesterification. The more commonly applied reaction is transesterification since it involves only a single step reaction between oil and methanol. Transesterification reaction can be carried out with or without the presence of a catalyst [1]. However, the use of a catalyst can reduce the production time by speeding up the reaction. There are three types of catalysts which are acid, base and enzyme. Acids catalysed transesterification is a slow reaction, therefore is not favourable [2]. On the other hand, enzymes are too costly. The cost of enzyme-catalyzed production of biodiesel is about twice that of the alkali-catalyzed process [3]. Therefore, this research focuses on the application of a base catalyst to produce biodiesel from rubber seed oil. Base catalysts can be in the form of a homogeneous catalyst which is soluble in the reaction medium or heterogeneous catalyst which are insoluble. However, the homogeneous base catalyst is sensitive to water and free fatty acid content in the feedstock where it will cause the formation of soap. This will cause difficulty in the purification of the biodiesel because soap will lead to the formation of oil-water emulsion [4].

Currently, the use of heterogeneous catalysts is gaining attention among researchers since they are reusable and therefore could save the production cost. These catalysts are in the form of metal oxides such as alkaline earth metal oxides, $\mathrm{MnO}$ and $\mathrm{TiO}[5,6]$. Even though these catalysts are reusable, but some studies have shown that they are subjected to leachate where part of the solid dissolves in the reaction medium and thus limiting the reusability [7]. An approach to overcome this problem is to bind the catalyst to a solid support. One of the materials that have been studied extensively as a support is an alumina.

As to evaluate the catalytic activity of alumina supported, they were used $\mathrm{KI}, \mathrm{CaO}$, and $\mathrm{CaO}-\mathrm{KI}$ to transesterify palm oil into biodiesel. The alumina supported-KI showed the highest conversion [8-10]. However, since palm oil is edible oil, then there is an issue of competition with the food supply. Moreover, there was reported, 925 million people were facing with malnutrition [11]. As such, in this research, we are utilizing rubber seed oil, which is a nonedible oil to produce biodiesel. The aim of this research is to compare the catalytic activity of alumina-CaO, alumina-KI, and alumina-CaO-KI in the transesterification of rubber seed oil with methanol.

\section{Materials and Methods}

Rubber seeds were collected from local rubber plantations. Aluminium oxide powder, potassium iodide and calcium acetate were purchased from R\&M Chemicals. Methanol (99\%) was from HmbG Chemicals. The chromatographic standards used were methyl heptadecanoate as internal standard and the FAME standard mixture GLC-10. Both were from Sigma-Aldrich. GLC-10 consists of methyl palmitate, methyl stearate, methyl oleate, methyl linoleate and methyl linolenate.

Rubber seeds were crushed, and the kernel was separated from the shell. The kernel was dried in the oven at $60{ }^{\circ} \mathrm{C}$ overnight and then milled by using a household blender. Rubber seed oil was extracted from the kernel by a Soxhlet extractor using petroleum ether for 6 hours. The solvent was evaporated in a rotary evaporator. The oil was then kept in a refrigerator.

Three types of catalysts were prepared. They are alumina-CaO-KI, alumina-CaO, and alumina-KI. The aluminaCaO-KI catalyst was prepared as follows. A $33.8 \mathrm{~g}$ of calcium acetate and $14 \mathrm{~g}$ of potassium iodide were dissolved in $100 \mathrm{~mL}$ water in a beaker. Then $40 \mathrm{~g}$ of alumina was added to the mixture. The mixture was stirred for 4 hours at room temperature. Then it was dried in an oven at $100{ }^{\circ} \mathrm{C}$ overnight. The dried mixture was then calcined at $700{ }^{\circ} \mathrm{C}$ for 5 hours. The mass ratio of alumina: $\mathrm{CaO}$ : $\mathrm{KI}$ in the catalyst is 100: 30: 35 . The mass of $\mathrm{CaO}$ produced from calcium acetate was calculated based on TGA data. The alumina-CaO was prepared with the same method but without adding potassium iodide. Alumina-KI was also prepared with the method but without adding calcium acetate.

The Brunauer-Emmett-Teller (BET) surface area analysis of porous properties of the catalysts was determined by Micromeritis ASAP 2000. Adsorption $\mathrm{N}_{2}$ gas within 6 hours at $250{ }^{\circ} \mathrm{C}$ (de-gassed). Investigation of the chemical 
composition and morphology of the catalysts done by using FESEM-EDX (JSM 7800F). While, X-Ray Diffraction analysis (XRD) was achieved by using Rigaku with $\mathrm{Cu} \mathrm{K} \alpha \mathrm{X}$-ray as a source, $2 \theta$ range from $2^{\circ}$ to $80^{\circ}$ with step sizes of $0.02^{\circ}$, at a scanning speed of $1^{\circ} \mathrm{min}^{-1}$.

Transesterification reaction was carried out in a three-neck flask equipped with a thermometer, a condenser, and a magnetic stirrer. $10 \mathrm{~g}$ of rubber seed oil was mixed with $90 \mathrm{~g}$ methanol and various amounts of the catalyst. The amount of catalyst used were between 0 and $3.5 \%$ (weight percent to total reactants). The reactions were carried out at $65^{\circ} \mathrm{C}$ and stirred at $600 \mathrm{rpm}$ for 5 hours. After the reaction was completed, the catalyst was removed by filtration, and the reaction mixture was poured into a separatory funnel. Two layers formed where the lower layer is glycerol, and the upper layer is biodiesel (FAME) solution in methanol. The glycerol layer was discarded, and biodiesel was obtained from the upper layer by evaporation with a rotary evaporator. Reactions were also carried out at $25{ }^{\circ} \mathrm{C}$ and $40{ }^{\circ} \mathrm{C}$ using $2 \%$ catalyst loading to study the effect of temperature on the biodiesel yield.

Quantification of biodiesel was done by Agilent 7890B gas chromatographer equipped with 5977A MSD and Zebron ZB-Wax column ( $30 \mathrm{~m} \times 0.25 \mathrm{~mm} \times 0.25 \mu \mathrm{m})$. The injector and MS transfer-line temperatures were set at $240{ }^{\circ} \mathrm{C}$ and $280{ }^{\circ} \mathrm{C}$, respectively. The column temperature was held at $110{ }^{\circ} \mathrm{C}$ for 2 minutes and then programmed to $240{ }^{\circ} \mathrm{C}$ at $6{ }^{\circ} \mathrm{C} / \mathrm{min}$. The methyl esters were quantified by an internal standard method using methyl heptadecanoate as internal standard and compared against GLC-10 FAME standards (Supelco).

\section{Results and Discussion}

The BET surface area, pore volume and pore size of different catalysts from the previous and currently studies are reported in Table 1. Referring the table, the surface area of the catalysts is ranging from $4.9283-48.8130 \mathrm{~m}^{2} / \mathrm{g}$. The literature data of $\mathrm{Al}_{2} \mathrm{O}_{3}$ act as a catalyst showed ranging $120-265 \mathrm{~m}^{2} / \mathrm{g}$ of the surface area. The decreasing in surface area was considering the sequence of catalyst displacement on the metal oxide, $\mathrm{Al}_{2} \mathrm{O}_{3}$. During the impregnation and calcination method, the reduction of BET surface area also occurred and reflecting the pore volume and pore size. The phenomena were apparently due to the insertion of $\mathrm{CaO}$ or $\mathrm{KI}$ into pores and surface of $\mathrm{Al}_{2} \mathrm{O}_{3}$. An identical measurement has been discussed by several researchers [9, 10, 12-14]. Referring to this range of pore size ( 2 to $50 \mathrm{~nm}=$ mesopore), the average pore size of the catalysts ranged from 10.9 to $18.6 \mathrm{~nm}$ categorize as mesoporous type. Meanwhile, the pore diameter less than $2 \mathrm{~nm}$ is microporous and on top of $50 \mathrm{~nm}$ is macroporous.

Table 1. BET characterization of the catalysts.

\begin{tabular}{|c|c|c|c|c|c|c|}
\hline \multirow[b]{2}{*}{ Samples } & \multicolumn{2}{|c|}{ Asri et al. [10] } & \multirow{2}{*}{$\frac{\text { Zabeti et al. [9] }}{\mathrm{Al}_{2} \mathrm{O}_{3} / \mathrm{CaO}}$} & \multicolumn{3}{|c|}{ Present Study } \\
\hline & $\mathrm{Al}_{2} \mathrm{O}_{3} / \mathrm{CaO}$ & $\mathrm{Al}_{2} \mathrm{O}_{3} / \mathrm{KI} / \mathrm{CaO}$ & & $\mathrm{Al}_{2} \mathrm{O}_{3} / \mathrm{CaO}$ & $\mathrm{Al}_{2} \mathrm{O}_{3} / \mathrm{KI}$ & $\mathrm{Al}_{2} \mathrm{O}_{3} / \mathrm{KI} / \mathrm{CaO}$ \\
\hline $\begin{array}{l}\text { Surface area } \\
\left(\mathrm{m}^{2} / \mathrm{g}\right)\end{array}$ & 83.77 & 54.551 & 83.74 & 48.813 & 4.928 & 21.246 \\
\hline $\begin{array}{l}\text { Pore volume } \\
\left(\mathrm{cm}^{3} / \mathrm{g}\right)\end{array}$ & 0.135 & 0.083 & 0.223 & 0.148 & 0.022 & 0.058 \\
\hline $\begin{array}{l}\text { Pore size } \\
\left(\mathrm{x} 10^{-8} \mathrm{~m}\right)\end{array}$ & 3.421 & 3.821 & 63.37 & 1.212 & 1.860 & 1.092 \\
\hline
\end{tabular}

The crystal morphology exposes through the micrograph of the catalyst. The $\mathrm{CaO}$ and $\mathrm{KI}$ on the surface of amorphous $\mathrm{Al}_{2} \mathrm{O}_{3}$ create porous materials. The impregnation and calcination method, made spherical crystals on the surface become obvious needle-shaped spicules of $\mathrm{Al}_{2} \mathrm{O}_{3}$ with a porous apparent in all of the catalysts. As can be seen in Figure 1, no distinct different between $\mathrm{KI}$ and $\mathrm{KI} / \mathrm{CaO}$ samples thus propose highly dispersed on the surface of support catalyst. Also, notified the sustained structure of $\mathrm{Al}_{2} \mathrm{O}_{3}$ after impregnation with another compound was important. Almost similar observation reported by [8]. The composition of catalysts is displayed in EDX analysis. The result showed the existence of $\mathrm{Al}(29.55 \%), \mathrm{O}(18.69 \%)$ and $\mathrm{Ca}(7.04 \%)$ for $\mathrm{Al}_{2} \mathrm{O}_{3} / \mathrm{CaO}$. Meanwhile for $\mathrm{Al}_{2} \mathrm{O}_{3} / \mathrm{KI}$, confirms the composition of $\mathrm{O}(23.77 \%)$, I (23.48\%), $\mathrm{Al}(13.48 \%)$ and $\mathrm{K}(9.25 \%)$. Also, the EDX 
analysis showed the composition of $\mathrm{O}$ (34.94\%), $\mathrm{Al}(21.28 \%), \mathrm{I}(9.54 \%), \mathrm{K}(4.11 \%)$ and $\mathrm{Ca}(3.32 \%)$ for $\mathrm{Al}_{2} \mathrm{O}_{3} / \mathrm{KI} / \mathrm{CaO}$.
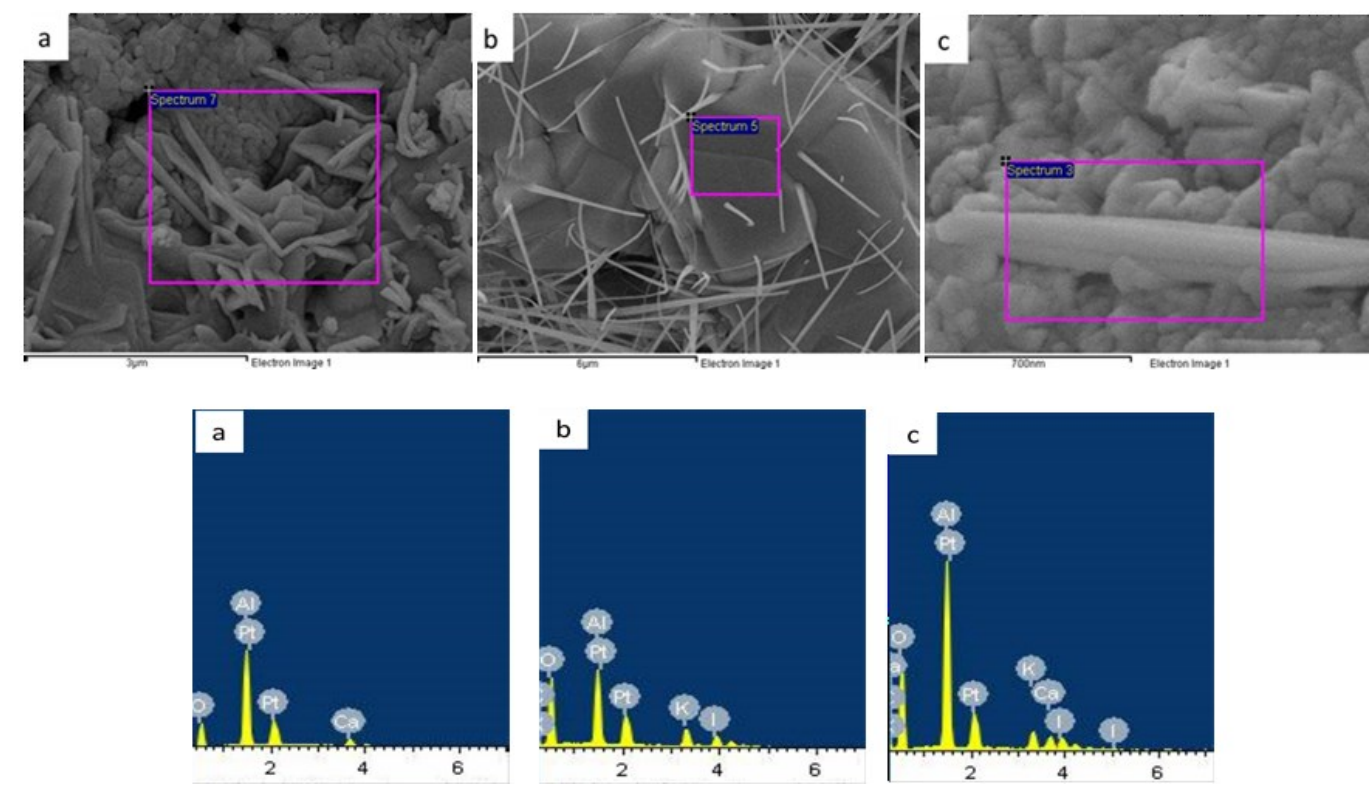

Figure 1. FESEM-EDX micrographs of (a) $\mathrm{Al}_{2} \mathrm{O}_{3} / \mathrm{CaO}$, (b) $\mathrm{Al}_{2} \mathrm{O}_{3} / \mathrm{KI}$ and (c) $\mathrm{Al}_{2} \mathrm{O}_{3} / \mathrm{KI} / \mathrm{CaO}$

The XRD profile of the catalysts is presented in Figure 2. The result demonstrated the characteristic peaks at $2 \theta$ ranging from $20^{\circ}$ to $70^{\circ}$. It showed large reflection at $29.66^{\circ}, 25.62^{\circ}$ and $25.46^{\circ}$, respectively and confirmed to be $\mathrm{Al}_{2} \mathrm{O}_{3}$. This is recommended that the structure of $\mathrm{Al}_{2} \mathrm{O}_{3}$ undefiled although loading with other compound. Meanwhile, small reflection of diffraction peaks from $\mathrm{KI}$ and $\mathrm{CaO}$ suggesting it was well dispersed on the surface of the support catalyst [15].

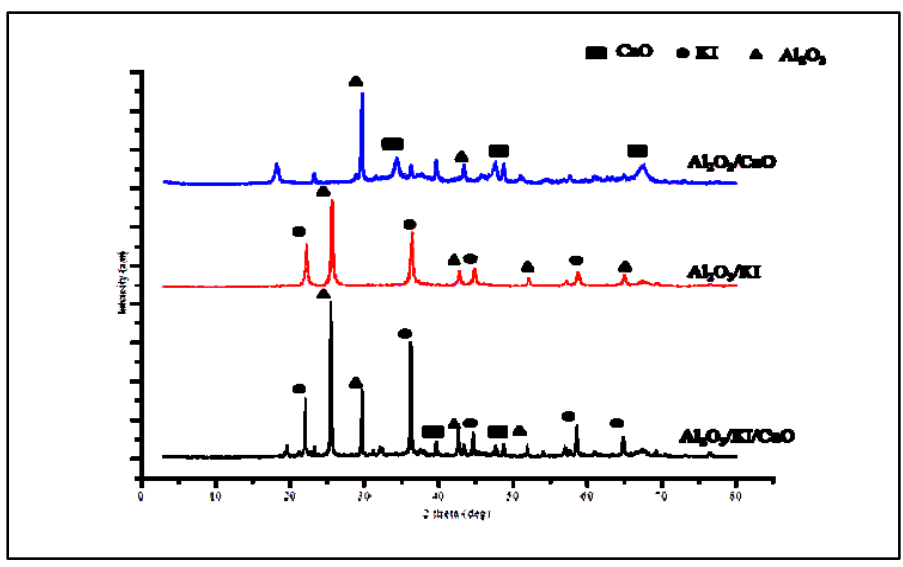

Figure 2. XRD patterns for the catalysts calcined at $700{ }^{\circ} \mathrm{C}$ for 2 hours

Production of biodiesel by transesterification of rubber seed oil refluxed with methanol was carried out by using three alumina-supported catalysts. Biodiesel yield was observed by varying the catalyst loading between 0 to $3.5 \%$. As shown in Figure 3, the yield increased with increasing catalyst loading from 0 to $2 \%$ loading for all of the 
catalysts. The highest yield of biodiesel with alumina $\mathrm{CaO}-\mathrm{KI}$, alumina-KI and alumina-CaO were 91.6\%, 90.7\% and $63.5 \%$ respectively. It was found that the optimal catalyst loading was at $2.0 \%$ but decreasing yield of biodiesel was observed with further increasing amount of catalyst. As expected, alumina-CaO-KI gave the highest yield of biodiesel probably due to the combination of factors; the high basicity of alumina-KI catalyst [16] and higher activity in the mild reaction condition of $\mathrm{CaO}$ catalyst [17]. Similarly, high biodiesel yield (95\%) was also observed from palm oil using same catalyst [10].

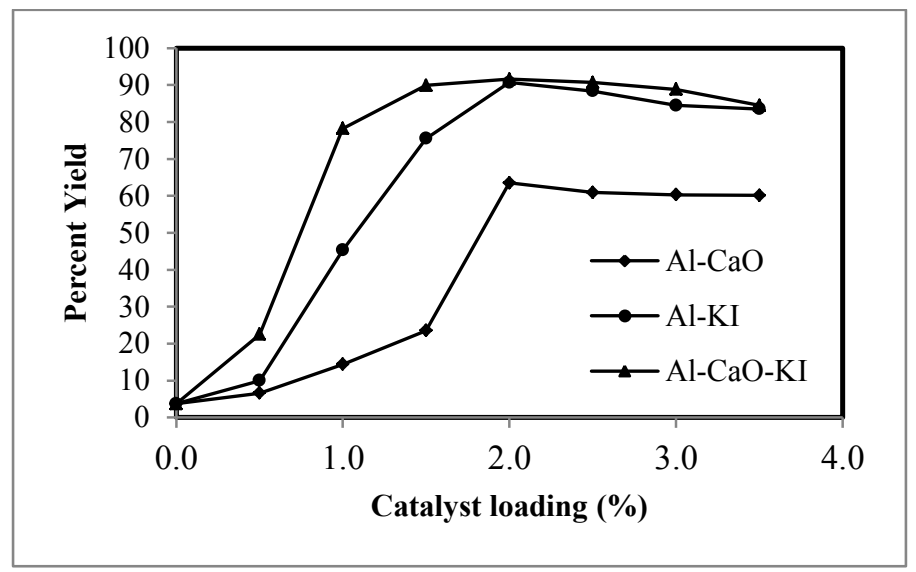

Figure 3. Effect of the catalyst loading on the biodiesel yield

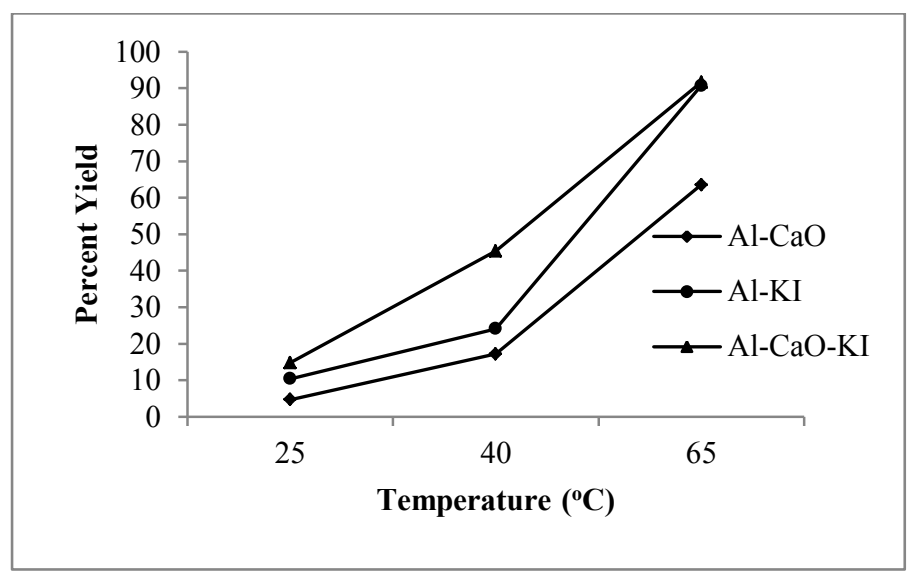

Figure 4. Effect of temperature on the biodiesel yield

The decline of biodiesel yield when the catalyst loading exceeded $2.0 \%$ was due to the mixing effectiveness of the reaction mixture. Beyond the optimum catalyst loading, there is a mass transfer limitation of the reactants. Previous studies by other researchers also showed the same trend $[18,19]$.

Calcium oxide is a popular heterogeneous catalyst because of its availability. However, the activity of this catalyst will decline after multiple uses due to leachate into the reaction medium. An approach to overcome this problem is to bind the calcium oxide onto a catalyst support such as alumina [9]. Other than calcium oxide, some potassium salts supported on alumina also showed high catalytic activity. Previously, it was discovered that alumina-supported potassium iodide with $35 \%$ KI loading gave the highest catalytic activity among several alumina-supported potassium salts [8]. It was also observed that when $\mathrm{CaO}$ was combined with this catalyst the optimum loading of 
$\mathrm{CaO}$ was $30 \%$ as used in our study [10]. In this study, we tried to investigate whether a combination of $\mathrm{CaO}$ and $\mathrm{KI}$ supported onto alumina gives a higher catalytic activity compared to when any of them are used separately. Amazingly, the alumina-CaO-KI catalyst was capable of producing higher biodiesel yields compared to alumina$\mathrm{CaO}$ or alumina-KI.

According to Figure 4, the yield increased drastically when the temperature was raised from $25^{\circ} \mathrm{C}$ to $65^{\circ} \mathrm{C}$. At $25^{\circ} \mathrm{C}$ the yield for all catalysts was only between $4.7 \%$ and $14.8 \%$, whereas at $65^{\circ} \mathrm{C}$ it was between $63.5 \%$ and $91.6 \%$. At all temperatures, Alumina-CaO-KI gave the highest yield. The study was done only up to a maximum reaction temperature of $65^{\circ} \mathrm{C}$ because it is the boiling temperature of methanol and thus, the highest temperature that can be achieved by refluxing. Moreover, to increase the temperature beyond that, special equipment is required. Previously, a study using alumina-supported $\mathrm{CaO}$ as a catalyst also showed a drastic increase in biodiesel yield between $55{ }^{\circ} \mathrm{C}$ and $65{ }^{\circ} \mathrm{C}$ [9]. Similarly, the same trend was also observed using a catalyst made of a mixture of calcium oxide and manganese oxide [20].

\section{Conclusion}

Biodiesel was successfully produced from rubber seed oil by transesterification with methanol using aluminasupported $\mathrm{CaO}-\mathrm{KI}$ as the catalyst. In this research, we have studied the activity of three types of alumina-supported catalysts, namely alumina-supported $\mathrm{CaO}$, alumina-supported $\mathrm{KI}$ and alumina-supported $\mathrm{CaO}$-KI. It was proven that a combination of $\mathrm{CaO}$ and $\mathrm{KI}$ supported onto alumina had a higher catalytic activity than any of the salts supported separately onto alumina. The highest biodiesel yield achieved was $91.6 \%$ using alumina-CaO-KI (100:30:35) with a $2.0 \%$ catalyst loading.

\section{Acknowledgement}

The authors acknowledge the Ministry of Higher Education Malaysia and Universiti Teknologi MARA, Pahang for funding the work through RAGS Grant (011000150004), UMP PGRS (170311) and for scholarship (Khazaai, S.N.M).

\section{References}

1. Patel, A., Brahmkhatri, V. and Singh, N. (2013). Biodiesel production by esterification of free fatty acid over sulfated zirconia. Renewable Energy, 51: 227-233.

2. Lee, D., Park, Y. and Lee, K. (2009). Heterogeneous base catalysts for transesterification in biodiesel synthesis. Catalysis Surveys from Asia, 13: 63-77.

3. Jegannathan, K. R., Eng-Seng, C. and Ravindra, P. (2011). Economic assessment of biodiesel production: Comparison of alkali and biocatalyst processes. Renewable and Sustainable Energy Reviews, 15: 745-751.

4. Talebian-Kiakalaieh, A., Amin, N. A. S. and Mazaheri, H. (2013). A review on novel processes of biodiesel production from waste cooking oil. Applied Energy, 104: 683-710.

5. Helwani, Z., Othman, M. R., Aziz, N. and Kim, J. (2009). Solid heterogeneous catalysts for transesterification of triglycerides with methanol: A review. Applied Catalysis A: General, 363: 1-10.

6. Gombotz, K., Parette, R., Austic, G., Kannan, D. and Matson, J. V. (2012). MnO and TiO solid catalysts with low-grade feedstocks for biodiesel production. Fuel, 92: 9-15.

7. Kouzu, M., Hidaka, J., Komichi, Y., Nakano, H. and Yamamoto, M. (2009). A process to transesterify vegetable oil with methanol in the presence of quicklime bit functioning as solid base catalyst. Fuel, 88: 19831990.

8. Xie, W. and Li, H. (2006). Alumina-supported potassium iodide as a heterogeneous catalyst for biodiesel production from soybean oil. Journal of Molecular Catalysis A: Chemical, 255: 1-9.

9. Zabeti, M., Daud, W. M. A. W. and Aroua, M. K. (2010). Biodiesel production using alumina-supported calcium oxide: An optimization study. Fuel Processing Technology, 91: 243-248.

10. Asri, N. P., Savitri, S. D., Suprapto, B. K. and Roesyadi, A. (2012). Development of heterogeneous alumina supported base catalyst for biodiesel production. Environment and Chemistry, 46: 116-121.

11. Maniam, G. P., Hindryawati, N., Nurfitria, I., Manaf, I. S. A., Ramachandran, N. and Rahim, M. H. A. (2015). Utilization of waste fat from cat fish (Pangasius) in methyl esters preparation using $\mathrm{CaO}$ derived from waste marine barnacle and bivalve clam as solid catalysts. Journal of the Taiwan Institute of Chemical Engineers, 49: 58-66. 
12. Umdu, E. S. and Seker, E. (2012). Transesterification of sunflower oil on single step sol-gel made $\mathrm{Al}_{2} \mathrm{O}_{3}$ supported $\mathrm{CaO}$ catalysts: Effect of basic strength and basicity on turnover frequency. Bioresource Technology, 106: 178-181.

13. Pasupuletey, N. Gunda, K., Liu, Y., Rempel, G. L. and Ng, F. T. T. (2013). Production of biodiesel from soybean oil on $\mathrm{CaO} / \mathrm{Al}_{2} \mathrm{O}_{3}$ solid base catalyst. Applied Catalysis: A General, 452: 189-202.

14. Islam, A., Taufiq-Yap, Y. H., Chu, C. M., Ravindra, P. and Chan, E. S. (2013). Transesterification of palm oil using $\mathrm{KF}$ and $\mathrm{NaNO}_{3}$ catalysts supported on spherical millimetric $\gamma-\mathrm{Al}_{2} \mathrm{O}_{3}$. Renewable Energy. 59: 23-29.

15. Farooq, M. and Ramli, A., Subbarao, D. (2013). Biodiesel production from waste cooking oil using bifunctional heterogeneous solid catalysts. Journal of Cleaner Production. 59: 131-140.

16. Evangelista, J. P. D. C., Gondim, A. D., Souza, D. L. and Araujo, A. S. (2016). Alumina-supported potassium compounds as heterogeneous catalysts for biodiesel production: A review. Renewable and Sustainable Energy Reviews, 59: 887-894.

17. Boey, P.-L., Maniam, G. P. and Hamid, S. A. (2009). Biodiesel production via transesterification of palm olein using waste mud crab (Scylla serrata) shell as a heterogeneous catalyst. Bioresource Technology, 100 (24): 6362-6368.

18. Nur, Z. A. S., Taufiq-Yap, Y. H., Nizah, M. F. R., Teo, S. H., Syazwani, O. N. and Islam, A. (2014). Production of biodiesel from palm oil using modified Malaysian natural dolomites. Energy Conversion and Management, 78: 738-744.

19. Xie, W. and Zhao, L. (2013). Production of biodiesel by transesterification of soybean oil using calcium supported tin oxides as heterogeneous catalysts. Energy Conversion and Management, 76: 55-62.

20. Dias, M. J., Alvim-Ferraz, M. C. M., Almeida, M. F., Diaz, J. D. M., Polo, M. S. and Utrilla, J. R. (2012). Selection of heterogeneous catalysts for biodiesel production from animal fat. Fuel, 94: 418-425. 